\title{
Translating sustainable diets into practice: the potential of public food procurement
}

\author{
Roberta Sonnino \\ Cardiff University - Cardiff - Reino Unido
}

\begin{abstract}
Building on widespread calls for policies and development strategies that align human and ecological goals, an increasing number of scholars and practitioners are turning to the concept of "sustainable diet" as a guiding principle to address the multidimensional implications of food production on society, the environment and the economy. After discussing the core principles of this concept and providing some examples of its practical application, this article explores the potential of food procurement in progressing sustainable diets in public canteens. A critical review of the literature shows that there are three main barriers that need to be overcome to embed the principles of "sustainable diet" in public contracts: the primacy of a rigid 'value for money' ethos, which reinforces a riskaverse culture around public food provision that inhibits individuals and organisations from driving change; the tendency by governments to promote 'silo-ed' approaches to change leadership on issues like public procurement, which inhibit the levels of knowledge-sharing and collective endeavor across departments that is required to underpin sustainable procurement reform; and a lack of technical knowledge related to sustainable procurement and sustainable food provision.
\end{abstract}

Keywords: Sustainable development. Consumption. Production.

\section{A tradução de dietas sustentáveis na prática: o potencial da contratação de alimentos públicos}

\section{Resumo}

Com base em apelos generalizados por políticas e estratégias de desenvolvimento que alinhem objetivos humanos e ecológicos, um número crescente de estudiosos e profissionais está recorrendo ao conceito de "dieta sustentável" como um princípio orientador para abordar as implicações multidimensionais da produção de alimentos na sociedade, no meio ambiente e na economia. Depois de discutir os princípios fundamentais deste conceito e fornecer alguns exemplos da sua aplicação prática, este artigo explora o potencial da aquisição de alimentos no desenvolvimento de dietas sustentáveis em compras públicas de alimentos. Uma revisão crítica da literatura mostra que há três barreiras principais que precisam ser superadas para incorporar os princípios da "dieta sustentável" nas compras públicas: a primazia de um ethos rígido, "value for money", que reforça uma cultura avessa 
ao risco em torno da provisão de alimentos públicos que inibe indivíduos e organizações de impulsionar a mudança; a tendência dos governos de promover abordagens "silenciadas" para mudar a liderança em questões como as compras públicas, que inibem os níveis de compartilhamento de conhecimento e esforço coletivo entre os departamentos necessários para sustentar a reforma sustentável de aquisições; e falta de conhecimento técnico relacionado a compras sustentáveis e fornecimento sustentável de alimentos.

Palavras-Chave: Desenvolvimento sustentável. Consumo. Produção.

\section{La traducción de dietas sostenibles en la práctica: el potencial de la contratación de alimentos públicos}

\section{Resumen}

Con base en llamamientos generalizados por políticas y estrategias de desarrollo que alinean objetivos humanos y ecológicos, un número creciente de estudiosos y profesionales está recurriendo al concepto de "dieta sustentable" como un principio orientador para abordar las implicaciones multidimensionales de la producción de alimentos en la sociedad, en el medio ambiente y en la economía. Después de discutir los principios fundamentales de este concepto y proporcionar algunos ejemplos de su aplicación práctica, este artículo explora el potencial de la compra de alimentos en el desarrollo de dietas sostenibles en compras públicas de alimentos. Una revisión crítica de la literatura muestra que hay tres barreras principales que deben ser superadas para incorporar los principios de la dieta sostenible en las compras públicas: la primacía de un ethos rígido, "value for money", que refuerza una cultura aversión al riesgo en torno de la provisión de alimentos públicos que inhibe a individuos y organizaciones de impulsar el cambio; la tendencia de los gobiernos de promover enfoques "silenciados" para cambiar el liderazgo en cuestiones como las compras públicas, que inhiben los niveles de intercambio de conocimiento y esfuerzo colectivo entre los departamentos necesarios para sostener la reforma sostenible de adquisiciones; y falta de conocimiento técnico

Palabras-Clave: Desarrollo sostenible. Consumo. Producción.

\section{Introduction: The (Un-)sustainability of the food system}

The concept of 'sustainability' has become a guiding development principle over recent decades, rhetorically at least. With regards to food, it is generally agreed that a sustainable food system should encompass environmental integrity, economic viability and social equity, along with inevitable trade-offs due to potential conflicts between these goals (Hinrichs 2010). This is particularly an issue for policymakers, who have a responsibility to take into account the sensitive relationship between socio-economic priorities, food production, human and environmental health (McMichael 2005).

Long-running and emerging issues, both globally and locally, ensure that debates about the nature of a sustainable food system and the key priorities for policy action are in constant flux. Morgan and Sonnino (2010) suggest these emerging challenges represent a 'new food equation', one where the food system must be valued in broader terms than in the past (Morgan 2015b) in order to account for the wider context of climate change, increasing energy costs, social unrest, financial instability and increasing environmental degradation (Koohafkan et al. 2012). The growth of these issues as interconnected sustainability concerns (Lang 2014; Sonnino 2016) raises new questions for the governance of food, including 
potential shifts in responsibilities between the state, private and civic sectors (Marsden and Morley 2014).

In the context of climate change, population growth and a depleting resource base, one of the greatest political dilemmas of the day is: "how to make food production more environmentally sustainable and resilient while feeding more people more effectively?" (Garnett 2013, pp.29-30). This question has traditionally been addressed through a "productionist" paradigm in which the emphasis is on producing more food, rather than moderating consumption (Lang and Heasman 2015). The enormous agricultural advances in chemicals, transport and agricultural technologies have facilitated global population growth and improved diets for many. Unfortunately this approach also carries significant costs and trade-offs (Fischer and Garnett 2016; Allen and Prosperi 2016), whilst exposing the extreme vulnerabilities of a food system that is inherently connected to the global ecosystem.

Growing evidence over the years has highlighted the many negative impacts of the food system on the environment, public health and social justice (Lang 2014). As Garnett (2013) summarizes, the food supply chain jeopardises our clean air and water, healthy soils, biodiversity and a climate to which we are adapted. Indeed, the food system generates an estimated 30\% of global greenhouse gas (GHG) emissions, is the dominant driver of deforestation and biodiversity loss and has severe consequences as a user and polluter of increasingly scarce water supplies (Garnett et al. 2015). Food waste alone is estimated to represent 3-5\% of total global warming impacts (European Commission 2014).

Since 2008, it has become apparent that sustainable food security is no longer an issue only for developing countries (Morgan and Sonnino 2010; Marsden and Morley 2014; Holt Giménez and Shattuck 2011). This period has seen hunger reemerge as a social and political reality for many individuals and households also in rich countries (Dowler and Lambie-Mumford 2015; Dowler et al. 2011). Ensuring that low-income households can afford and have access to nutritious food requires tackling the systemic causes of poverty and addressing the broader environmental and economic challenges to the food system. In practice, this entails adopting a systemic approach, based on the recognition that an unsustainable food system is shaped by both issues of production and consumption.

As our global population grows, urbanises and becomes wealthier, it is demanding more resource intensive, energy rich foods - notably animal products - potentially damaging the environment further and exacerbating problems of obesity and chronic diseases (Garnett 2014b, p.3).

It is estimated that the food system leaves almost one billion people hungry. An even greater number of people (1.5 billion) are overweight or obese (Lang 2014; Oxfam 2012), a figure that has doubled since 1980 (WHO 2014). Dietary changes, especially the increased consumption of processed foods high in salt and sugar, have long been recognised as a significant contributor to hypertension, heart disease and stroke (WHO 2014) along with increasing the risk of type 2 diabetes (WHO 2016). A large proportion of people have an imbalanced diet that does not provide the essential nutrients for health development (Garnett 2013; Burlingame and Dernini 2010). This is a critical public health concern. Globally, there are around 1.7 million 
annual deaths resulting from excessive sodium intake (WHO 2014). Approximately 1.5 million deaths in 2012 were linked to diabetes (WHO 2016).

While these changes to consumption have measurable public health consequences, they also add to ecological pressures (Lang and Barling 2012; Garnett 2013; McMichael 2005). A key dietary dimension of the impact on ecological pressures, particularly in terms of carbon emissions, is the level of animal product consumption. Rearing livestock for meat, eggs and milk generates some $14.5 \%$ of total GHG emissions as well as utilising 70\% of agricultural land (Fischer and Garnett 2016). Figure 1 from the Barilla Center for Food and Nutrition (BCFN) compares the environmental impact of a meat-based diet with a vegetarian and partially vegetarian diet.

Figure 1 - A comparison between diets in relation to environmental impact

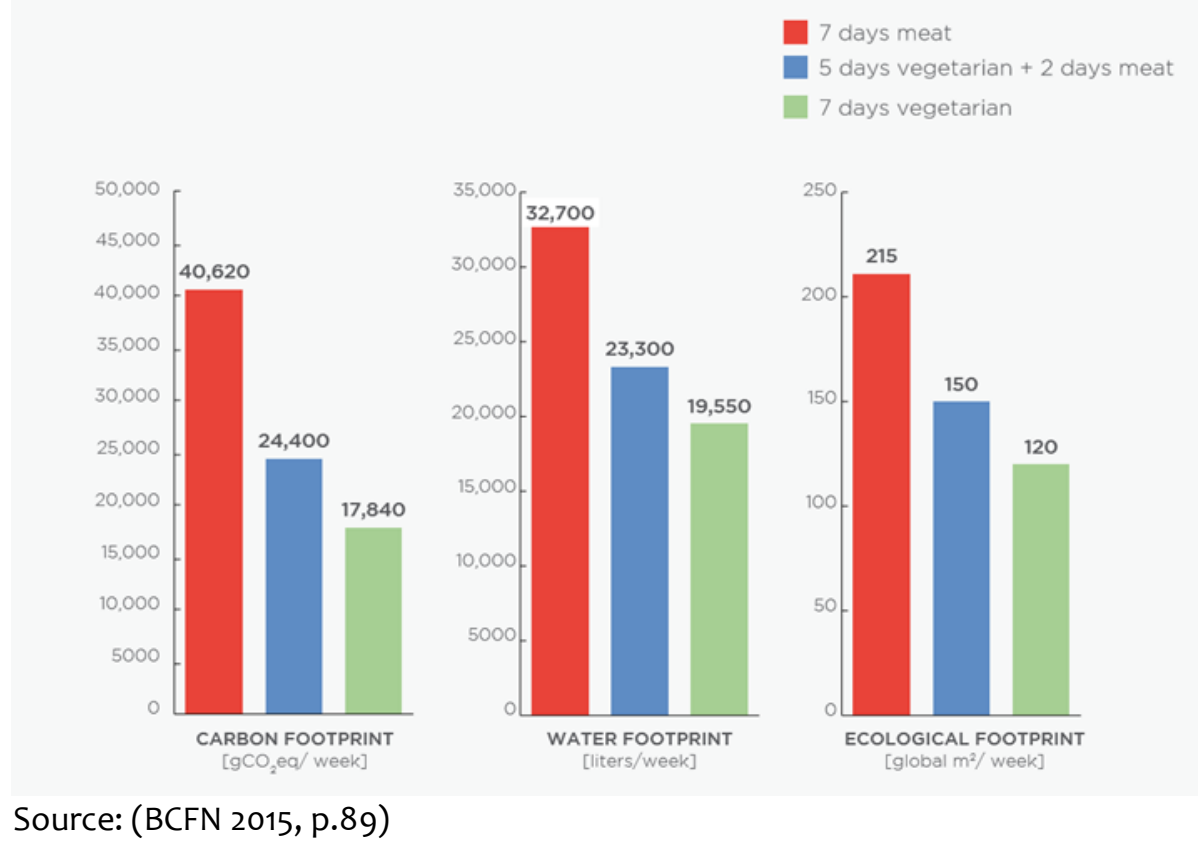

Clearly, there is a global need to focus on consumption as well as production in order to align health and environmental goals (Fischer and Garnett 2016). Environmental, health and malnutrition effects are interconnected and interactive issues (Lang 2014). Key to understanding this relationship is to factor into the equation the effects of food production on human health and the environment from farm to fork. As I will explain in the next section, the concept of "sustainable diet" is a particularly useful devise to progress this understanding - within and beyond academic debates.

\subsection{Sustainable Diets: Balancing Human and Environmental Health}

There is growing evidence that suggests a strong compatibility between diets with low environmental impacts and those better for health - described as a 'sustainable healthy diet' (Garnett 2015). An FAO and Biodiversity International symposium held in Rome in 2010 defined a sustainable diet as: a diet that has a low environmental impact on the planet's resources now and into the future, is based on respecting biodiversity, ecosystems and animal welfare, and contributes to a 
nutritious, affordable, culturally appropriate diet that promotes a healthy life for all (Burlingame and Dernini 2010, p.7). Crucially, this definition (see Figure 2) highlights the connection between the multiple impacts of food on human health and environmental health - including climate change.

\section{Figure 2 - Issues to consider when defining a sustainable diet}

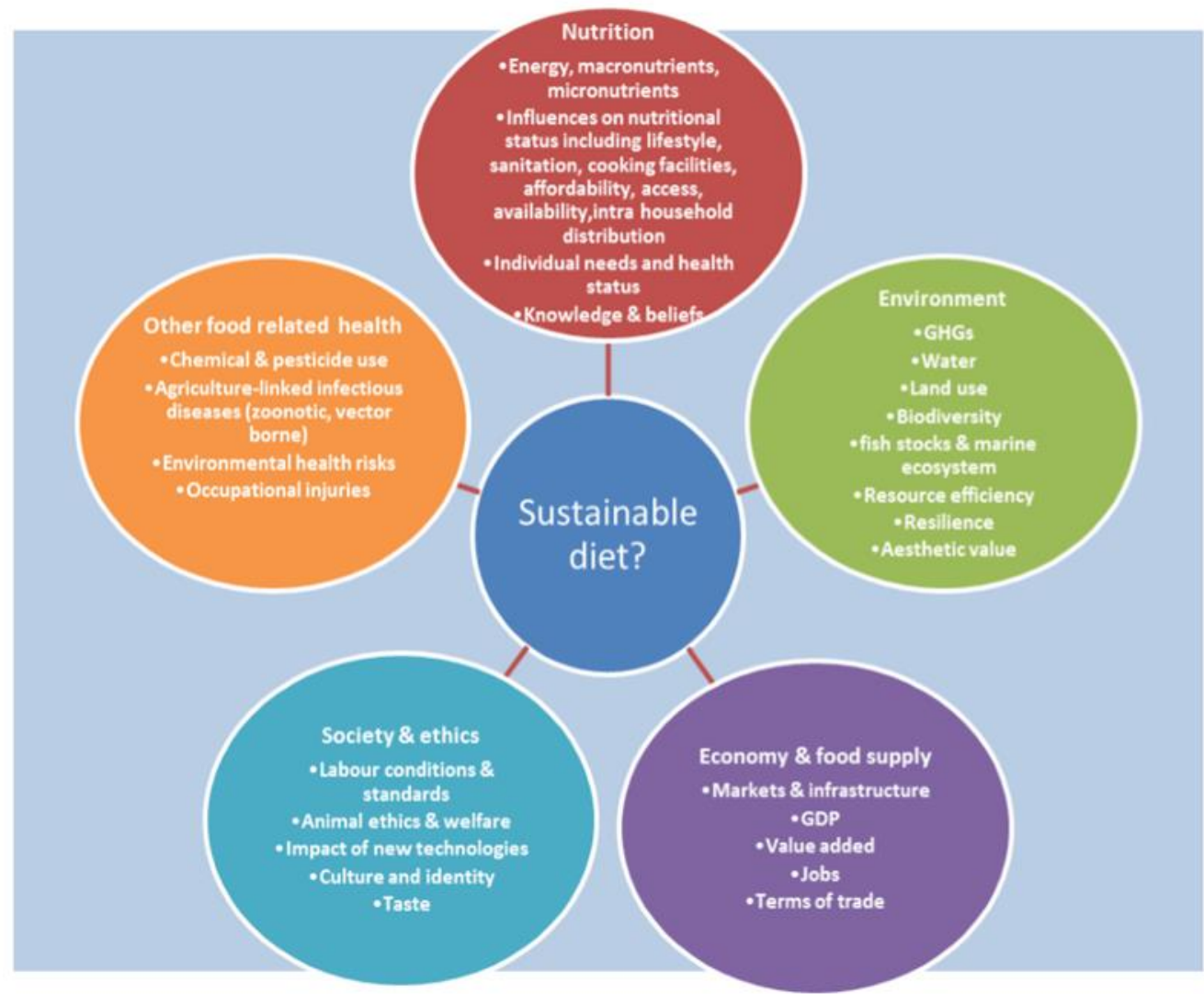

Source: (Garnett 2014b, p.5).

A comprehensive literature review conducted by Garnett (2014a) identified and summarised the characteristics of a sustainable healthy diet as the following:

Diversity in foods eaten;

Balance between energy intake and energy needs;

High consumption of tubers and whole grains; legumes; fruits and vegetables - particularly those that are field grown and less transport-intensive; Reduction in meat consumption;

Dairy products eaten in moderation;

Unsalted seeds and nuts;

Small quantities of fish from certified sources;

Very limited consumption of food high in fat, sugar or salt and low in micronutrients (crisps, confectionary, sugary drinks); olive oil);

Use of oils and fats with a beneficial omega 3:6 ratio (such as rapeseed and

Tap water in preference of other beverages. 
It is also worth noting that these are loose guidelines that allow for dietary variations throughout the world and culturally-appropriate diets - there is no 'globodiet' (Lang 2014, p.240).

In Italy, the BCFN (2015) developed the concept of a 'double pyramid' to demonstrate how nutritious and health foods (such as fruit, vegetables, wholegrains, and pulses) least environmentally harmful, while foods that should be consumed in moderation, particularly for health reasons (for example, red and processed meats), are most environmentally harmful (see Figure 3).

\section{Figure 3 - The 'double pyramid' of healthy food and environmental sustainability} ENVIRONMENTAL PYRAMID

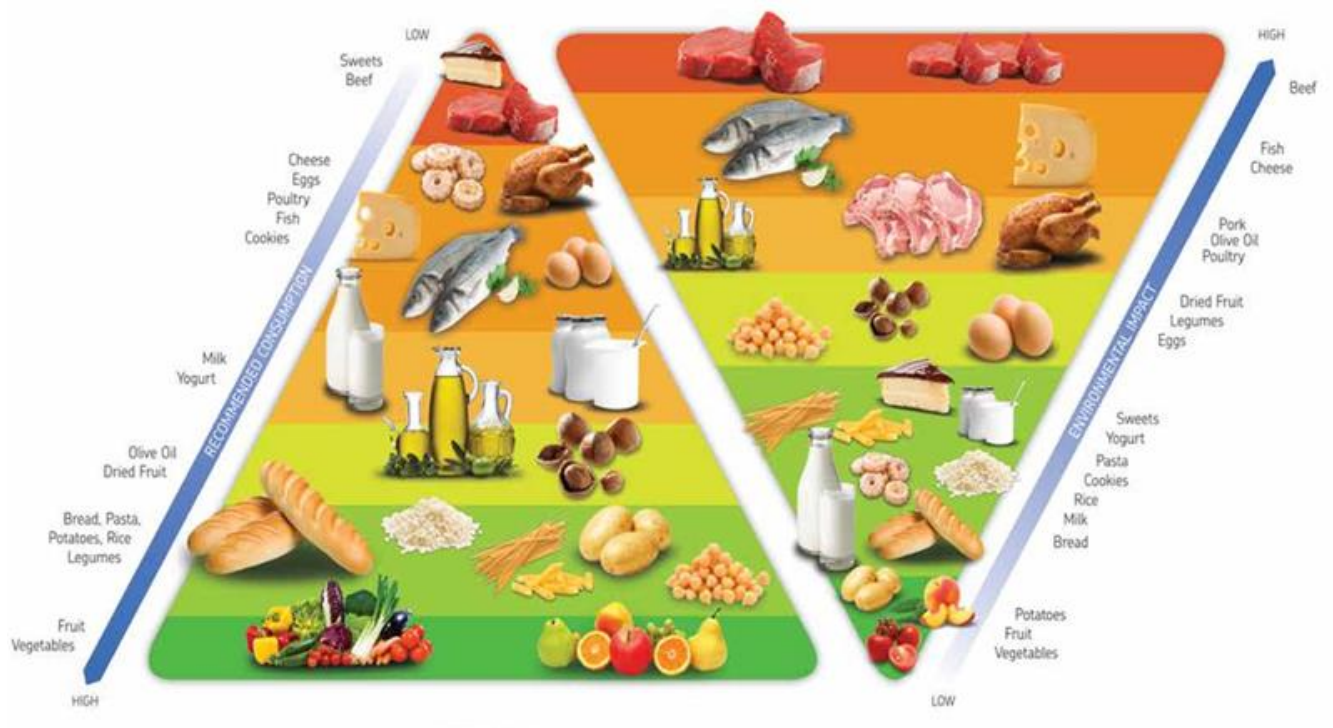

FOOD PYRAMID

A comparative analysis by BCFN highlighted the significant environmental impact of a meat-based menu in comparison with each of the others (BCFN 2015). The report documents that not eating meat one day per week for a year is equal to a $\mathrm{CO}_{2}$ saving that is emitted from a $2400 \mathrm{~km}$ car-journey (BCFN 2015). This demonstrates the potential of altering diets as a practical way to engender sustainability generally.

The concept of sustainable diet has slowly appeared on the agenda of governments, health organisations and even commercial food companies (Kramer et al. 2017). In the UK, for example, governmental eating advice is primarily based on nutrient recommendations for health. The Eatwell Guide (see figure 4), published in 2016, is the principle consumer facing guide to healthy eating. Developed collaboratively by Public Health England, Food Standards Scotland, Welsh Government and the Food Standards Agency in Northern Ireland, the guide is an iteration of the Eatwell Plate, which evolved from the 'Balance of Good Health' plate launched in 1994. 
Figure 4 - The Eatwell Guide

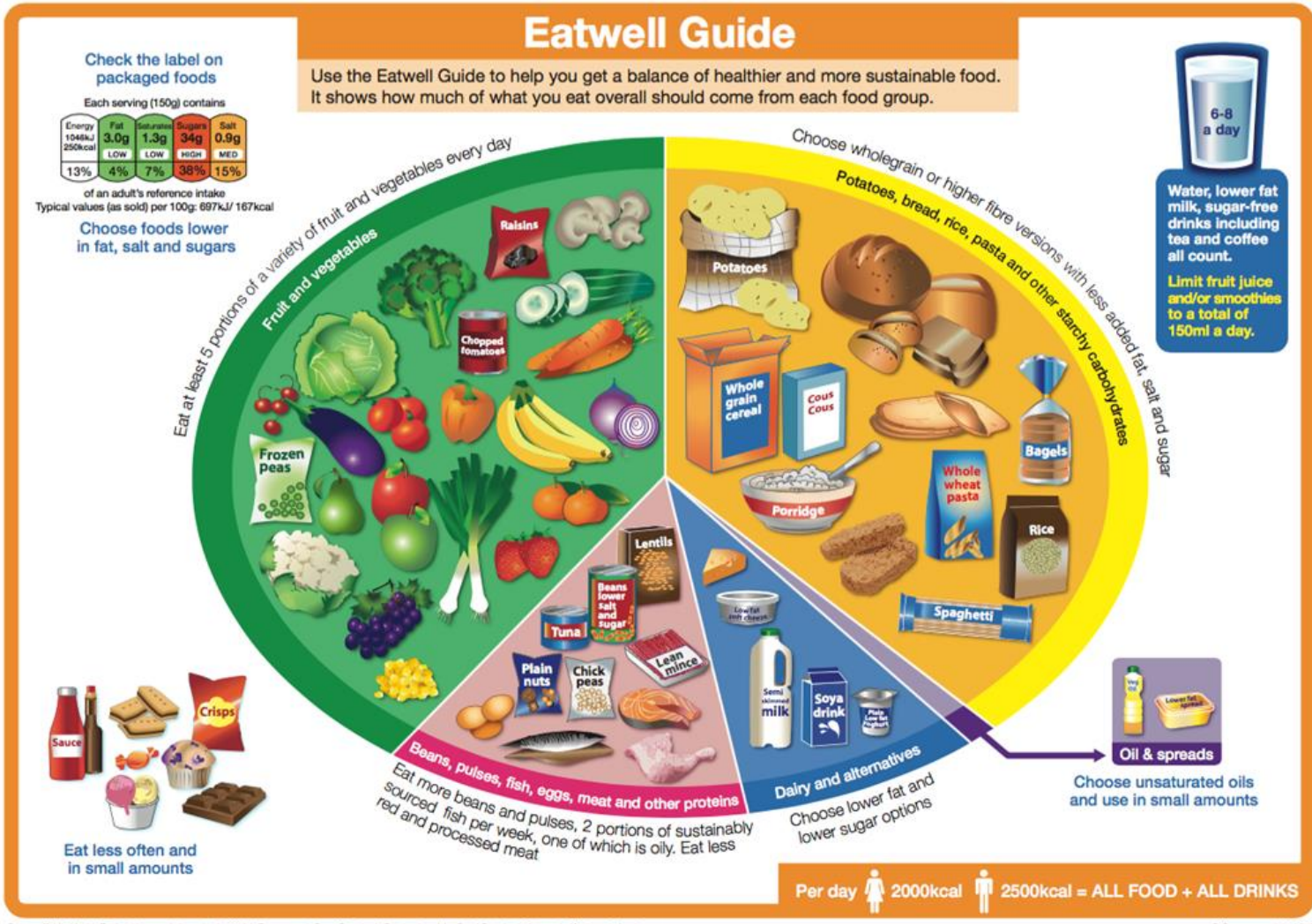

The Eatwell Guide states that its recommendations demonstrate an "appreciably lower environmental impact than the current UK diet", with a carbon footprint 32\% lower than the current national average diet. However, as discussed in the Medact and Eating Better Alliance Policy Briefing Report (2017) 'A Healthy and Sustainable Food Future', the influence of sustainability considerations is not outlined in detail in the Guide, particularly regarding guidance for consumption of different meat and dairy products (Public Health England 2016b).

The World Wildlife Fund has built on the Eatwell approach to diets by seeking to explicitly link health and environmental outcomes. The Livewell Framework was originally published in 2011 and was updated in 2017 (Macdiarmid et al. 2011). The overarching aim of the WWF Livewell framework is to promote food sustainability and outline the changes that need to be made in order to achieve a 'One Planet Future', where resources are equitably consumed across nations and generations. The first Livewell report (Macdiarmid et al. 2011) sought to develop a Livewell Plate and a Livewell 2020 diet that would both meet current dietary requirements, but also the One Planet Food programme goal of a $25 \%$ reduction of GHG emissions from food production and consumption by 2020. In terms of food consumption, the Livewell approach sets out to demonstrate that changing the balance of our diets could significantly lower our environmental impact by reducing carbon emissions from the food supply chain. Guiding this is a definition of a sustainable diet based on six Livewell Principles for a sustainable and healthy diet (Kramer et al. 2017):

1. Eat more plants - enjoy vegetables and whole grains

2. Eat a variety of foods - have a colourful plate 
3. Waste less food - one third of food produced for human consumption is lost or wasted.

4. Moderate your meat consumption, red and white - enjoy other sources of proteins such as peas, beans and nuts.

5. Buy food that meets a credible certified standard - consider MSC, free-range and fair trade.

6. Eat fewer foods in high fat, salt and sugar - keep food such as cakes, sweets and chocolate as well as cured meat, fries and crisps to an occasional treat. Choose water, avoid sugary drinks and remember that juices only count as one of your five-a-day, however much you drink.

It is clear that encouraging people to transition to a low-carbon, sustainable diet is not a simple process, but permeated with complex cultural and socio-economic factors (Montagu 2016). As regard public food catering, ideally the healthy diet approach can guide decisions when developing sustainable menus. However, in the context of tight budgets, this will inevitably involve trade-offs between cost and the various aspects of sustainability. For example, the Livewell report (Macdiarmid et al. 2011) stated that, while a reduction in meat could satisfy environmental and public health pressures, this may have consequences for farming and other employment in the UK that need to be considered (Macdiarmid et al. 2011).

\section{Public Food Provisioning: A Transition to a More Sustainable Food System}

Public procurement - the process through which public bodies purchase goods and services - is becoming increasingly recognised as a tool to address some of the challenges of an unsustainable food system (see, for example: Ashe and Sonnino 2013; Lehtinen 2012; Smith et al. 2016). There is growing recognition of the "power of purchase" to foster a healthier food system (Morgan and Morley 2014) and link issues of public health, economic development, democracy and environmental integration (Morgan and Sonnino 2013). Indeed, schools, hospitals, care homes and prisons are the most prominent public food institutions today, and carry particular resonance because they feed the most vulnerable people in our societies - patients, pupils, pensioners and prisoners (Morgan and Morley 2014).

Evidence suggests that improving the nutritional quality and dining environments of school food can not only help to tackle childhood obesity, but may also result in improved academic performance, engagement and classroom concentration (School Food Trust 2015; School Meals Review Panel 2005). Likewise, hospitals are in a key position to reflect their primary prevention messages in the food that they provide (Lagasse and Neff 2010). It is in the interest of hospitals and the national public health service to be a "vehicle of improvement and a role model for food in the local community" by providing nutritious food appropriate to patient needs (Department of Health 2014, p.5).

Public food procurement has an enormous potential role to play in mitigating the impacts of diets and food on the environment as well as promoting social justice for vulnerable populations. This multifunctional potential of public food procurement has often been overlooked due to a priority generally placed on short-term cost 
saving and economic efficiency in public institutions - a perspective that is based on a very narrow interpretation of the concept of "value".

\title{
2.1 Defining 'value' in public sector catering
}

\begin{abstract}
If we are what we eat, then public sector food purchasers help shape the lives of millions of people. In hospitals, schools, prisons and canteens around the country, good food helps maintain good health, promote healing rates and improve concentration and behaviour. But sustainable food procurement isn't just about better nutrition. It's about where the food comes from, how it's produced and transported, and where it ends up. It's about food quality, safety and choice. Most of all, it's about defining best value in its broadest sense (DEFRA 2003).
\end{abstract}

This quote is drawn from the UK's Department for the Environment, Food And Rural Affairs' Public Sector Food Procurement Initiative (PSFPI), launched in 2003 (Morgan and Sonnino 2013; Morgan 2008), which was designed to increase consumption of nutritious food and reduce the environmental impacts of food production and consumption practices (Sonnino and McWilliam 2011).

As Morgan and Sonnino (2008) state, DEFRA's definition also uncovers a key problem when attempting to define a 'sustainable food system' for public procurement practice - a commonly agreed definition of 'best value'. Researchers agree that it is necessary to move from the dominant ethos of "value-for-money" to a "values-for-money" driven food system, shaped by ethical values that incorporate broader social goals than the conventional ones of price, convenience and safety (Lang 2010). Morgan and Sonnino (2007) advocate developing 'creative procurement policies', where a holistic view of the food chain can align consumption and production, with an emphasis on locally produced food as a foundation of sustainable school meals.

However, with austerity placing increasing financial pressure on local authorities, a real danger lies in cost-cutting within the public sector - a counterproductive measure that is especially evident in the public food realm, where cost displacement is visible in the short-term costs of nutritional poverty and long-term costs of healthcare (Morgan 2015a).

Several tools have been developed to help tackle these challenges in practice. Notably, a 'Balanced Scorecard' (see Figure 5) approach was developed by the UK Department for Environment, Food and Rural Affairs which aims to facilitate good procurement by 'balancing' more straightforward criteria (such as cost) with more complex criteria (such as health and wellbeing, resource efficiency and quality of service) (DEFRA 2014b). 
Figure 5 - The Balanced Scorecard

\begin{tabular}{|c|c|c|c|c|c|}
\hline \multicolumn{6}{|c|}{ Quality and Value } \\
\hline \multirow[t]{8}{*}{ Cost } & & & Service & & \\
\hline & Production & $\begin{array}{l}\text { Health \& } \\
\text { Wellbeing }\end{array}$ & $\begin{array}{l}\text { Resource } \\
\text { Efficiency }\end{array}$ & $\begin{array}{l}\text { Socio- } \\
\text { economic }\end{array}$ & $\begin{array}{l}\text { Quality of } \\
\text { Service }\end{array}$ \\
\hline & \multicolumn{5}{|c|}{ Requirements/Award Criteria Categories } \\
\hline & $\begin{array}{l}\text { Supply chain } \\
\text { management }\end{array}$ & Nutrition & Energy & $\begin{array}{l}\text { Fair \& ethical } \\
\text { trade }\end{array}$ & Food quality \\
\hline & $\begin{array}{l}\text { Animal } \\
\text { Welfare }\end{array}$ & $\begin{array}{c}\text { Food safety \& } \\
\text { hygiene }\end{array}$ & Water & $\begin{array}{l}\text { Equality \& } \\
\text { diversity }\end{array}$ & $\begin{array}{l}\text { Customer } \\
\text { satisfaction }\end{array}$ \\
\hline & Environment & $\begin{array}{l}\text { Authenticity \& } \\
\text { traceability }\end{array}$ & Waste ${ }^{\circ}$ & $\begin{array}{l}\text { Inclusion of } \\
\text { SMEs }\end{array}$ & \\
\hline & $\begin{array}{l}\text { Variety \& } \\
\text { seasonality }\end{array}$ & & & $\begin{array}{c}\text { Local \& cultural } \\
\text { engagement }\end{array}$ & \\
\hline & & & & $\begin{array}{l}\text { Employment \& } \\
\text { skills }\end{array}$ & \\
\hline
\end{tabular}

\subsection{Challenges to engendering change in public food provision}

While there is enormous potential for public food procurement to embed the principles of environmental and economic sustainability, along with human health and wellbeing, into the public sector, there are many barriers to enacting this potential in practice. In all, these can be grouped into three categories. First, as mentioned earlier, one of the biggest barriers is primacy of a rigid 'value for money' ethos, which limits the potential for creative and flexible procurement solutions and reinforces a risk-averse culture around public food provision that inhibits individuals and organisations from driving change (Morgan and Sonnino 2013, p. 134). Perceptions that sustainable food options drive-up cost, and that 'value for money' is not consistent with sustainability, further entrench a narrow 'efficiency' culture within the sector.

Second, the prevailing structures of government tend to promote 'silo-ed' approaches to change leadership on issues like public procurement, inhibiting the levels of knowledge-sharing and collective endeavor across departments that is required to underpin sustainable procurement reform (Morgan 2008). In particular, the lack of integrated approaches to dealing with sustainable public food procurement and its attendant issues, for example food waste, contribute to the lack of responsibility and ownership over tackling these issues (Sonnino and McWilliam 2011).

Third, there is also a lack of technical knowledge related to sustainable procurement and sustainable food provision (Morgan and Sonnino 2013). Strong leadership at political, administrative, cultural and commercial levels, along with clear goals, adequate resourcing and 'cross-departmental commitment and cooperation', are vital to implementing sustainable public food procurement (Smith et al. 2016, p. 252). 


\section{Implementing Changes from Farm-to-Fork to Create Sustainability in Public Sector Food Delivery}

Providing a definition and guidelines for 'healthy and sustainable menus' in practical terms may help deliver sustainable values in schools, hospitals and other public settings. Based on the general principles of a "sustainable diet", when sourcing of ingredients for a 'sustainable and healthy menu', the following should be taken into account:

environmental considerations: seasonal, locally produced, organic, meat and dairy reduction, increase in fruit and vegetables, procure food from suppliers with environmental standards or certificates, no processed foods, tap water over bottled and sugar-based drinks.

Health and social considerations: no processed foods or drinks, reduce/ban sugar- and salt-based foods and drinks, increase in fruit and vegetables on the menu, support Fairtrade suppliers, and provide culturally-appropriate food.

Economic considerations: support local producers and suppliers, potential long-term financial savings through health and environmental improvements, save money through meat reduction and reinvest in more environmentally sustainable foods, cooking large quantity foods such as soups (and similar meals) are cheap and healthy.

Other considerations include food storage methods, and cooking methods, as they impact on sourcing strategies and types of ingredients used.

To date, most initiatives have concentrated on the environmental dimension of sustainability, focusing in particular on climate change mitigation strategies. The introduction of a vegetarian school catering system in the city of Turin, Italy, for example, led to a reduction in the overall carbon foodprint of $32 \%$ (Cerutti et al. 2017). Indeed, reducing meat consumption is a common conclusion across studies of sustainable and healthy diets (see Macdiarmid et al. 2011; Kramer et al. 2017; Cerutti et al. 2017), which have increasingly framed the reduction of energy and waterintensive animal-based food products (meat and dairy) on institutional menus as a cost-effective climate mitigation strategy (Hamerschlag and Kraus-Polk 2017). Since meat is particularly vulnerable to 'shocks' caused by climate change (water shortages and temperature fluctuations), it "makes sense to reformulate menus so they rely less on meat, and to do it before costs become prohibitive" (Barling et al. 2016, p.27).

Furthermore, there is increasing citizen-consumer demand for a 'flexitarian' diet (consuming a predominately vegetarian diet with the infrequent addition of meat) or supporting global initiatives such as 'Meat Free Mondays' (whereby people commit to having at least one meat-free day each week). This also points to the potential of incorporating more plant-based high-protein dishes into public sector menus (see Figure 6).

Figure 6 - The multidimensional benefits of adopting a more plant-based menu 


\section{FOOD SHIFTS MATTER}

Over 2 years, Oakland Unified School District reshaped its menu with fewer animal foods and more protein-rich legumes and vegetables. This shift generated considerable water and climate benefits, and cost savings:

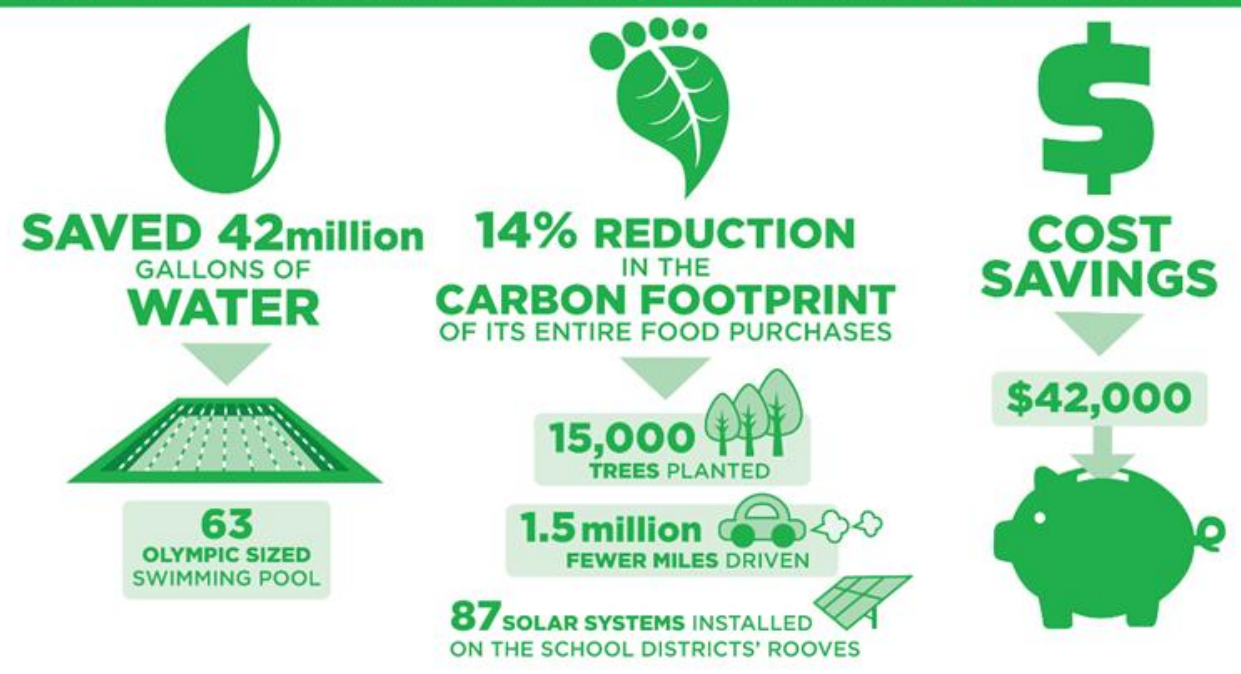

Source: OUSD (FOE 2010).

As initiatives such as Menus of Change in the USA have set out to demonstrate, "changing menus is a powerful... way to drive improvements in our health, our planet, and also is the most important part of doing business in the restaurant and food service industry" (Menus of Change, undated). Making explicit links between a healthy environment and healthy food through procurement will ensure the concept of a sustainable diet is understood by all stakeholders, from the general public to foodservice companies, and "will stimulate greater customer demand" (Barling et al. 2016, p.26). While these findings are particularly promising in terms of producing climate-friendly menus, more research is needed on the other dimensions of sustainability to ensure that the public sector begins to lead by example in making decisions that foster more inclusive and equitable (e.g., sustainable) food systems.

\section{REFERENCES}

Allen, T. and Prosperi, P. 2016. Modelling Sustainable Food Systems. Environmental Management 57(5), pp. 956-975

Ashe, L.M. and Sonnino, R. 2013. At the Crossroads: New Paradigms of Food Security, Public Health Nutrition and School Food. Public Health Nutrition 16(6), pp. 1020-1027

Barilla CFN 2015. Double Pyramid 2015: Recommendations for a Sustainable Diet. Barilla Centre for Food \& Nutrition, Parma 
Barling, L., Crossley, D. and Cura, A. 2016. Full Report - Catering For Sustainability: Making the Case for Sustainable Diets in Foodservice. Food Ethical Council, Sodexo and WWF

Burlingame, B. and Dernini, S. 2010. Sustainable Diets and Biodiversity: Directions and Solutions for Policy, Research and Action. FAO Food and Organization of the United Nation, Rome

Cerutti, A.K., Ardente, F., Contu, S., Donno, D. and Beccaro, G.L. 2017. Modelling, Assessing, and Ranking Public Procurement Options for a Climate-friendly Catering Service. The International Journal of Life Cycle Assessment. In Press, pp.1-21

DEFRA 2003. Unlocking opportunities: Lifting the Lid on Public Sector Food Procurement. Department for the Environment, Food and Rural Affairs, UK Government, London

Department of Health 2014. The Hospital Food Standards Panel's Report on Standards for Food and Drink in NHS Hospitals. Department of Health, UK Government, London

Dowler, E. et al. 2011. Thinking about 'Food Security': Engaging with UK Consumers. Critical Public Health 21(4), pp. 403-416

Dowler, E. and Lambie-Mumford, H. 2015. Introduction: Hunger, Food and Social Policy in Austerity. Social Policy and Society 14(3), pp. 411-415

European Commission 2014. Impact Assessment on Measures Addressing Food Waste to Complete Swd (2014) 207 Regarding the Review of EU Waste Management Target. European Commission, Brussels

Fischer, C.G. and Garnett, T. 2016. Plates, Pyramids, Planet. Oxford: FAO, the University of Oxford

FOE 2010. Healthy Planet Eating: How Lower Meat Diets Can Save Lives and the Planet. Friends of the Earth, UK. Available at: https:www.foe.co.uk/sites/default/files/douwnloads/healthy_planet_eating.pdf [Accessed: 9 July 2017]

Garnett, T. 2013. Food Sustainability: Problems, Perspectives and Solutions. Proceedings of the 34 Nutrition Society 72(1), pp. 29-39

Garnett, T. 2014a. Changing What We Eat: A Call for Research and Action on Widespread Adoption of Sustainable Healthy Eating. Food Climate Research Network, Oxford

Garnett, T. 2014b. What is a Sustainable Healthy Diet? Food Climate Research Network, Oxford 
Garnett, T. et al. 2015. Policies and Actions to Shift Eating Patterns: What Works? Food Climate Research Network, Oxford

Hamerschlag, K. and Kraus-Polk, J. 2017 Shrinking the Carbon and Water Foodprint of School Food: A Recipe for Combating Climate Change. A Pilot Analysis of Oakland Unified School District's Food Programs. Friends of the Earth U.S.

Hinrichs, C. 2010. Conceptualizing and Creating Sustainable Food Systems: How Interdisciplinarity Can Help. In: Blay-Palmer, A. ed. Imagining Sustainable Food Systems: Theory and Practice. Surrey: Ashgate Publishing Limited, pp. 17-35

Holt Giménez, E. and Shattuck, A. 2011. Food Crises, Food Regimes and Food Movements: Rumblings of Reform or Tides of Transformation? The Journal of Peasant Studies 38(1), pp. 109-144

Koohafkan, P. et al. 2012. Green Agriculture: Foundations for Biodiverse, Resilient and Productive Agricultural Systems. International Journal of Agricultural Sustainability 10(1), pp. 61-75

Lagasse, L. and Neff, R. 2010. Balanced Menus: A Pilot Evaluation of Implementation in Four San Francisco Bay Area Hospitals.

https://www.jhsph.edu/research/centers-and-institutes/johns-hopkins-center-for-alivable-future/research/clf_publications/pub_rep_desc/balanced_menu.html [Accessed on 19th November 2018]

Lang, T. 2014. Sustainable Diets: Hairshirts or a Better Food Future? Development 57(2), pp. 240-256

Lang, T. and Barling, D. 2012. Food Security and Food Sustainability: Reformulating the Debate. Geographical Journal 178(4), pp. 313-326.

Lang, T. and Heasman, M. 2015. Food Wars: The Global Battle for Mouths, Minds and Markets. Second Edition. Oxford: Routledge

Lehtinen, U. 2012. Sustainability and Local Food Procurement: a Case Study of Finnish Public Catering. British Food Journal 114(8), pp. 1053-1071

Macdiarmid, J. et al. 2011. Livewell: a Balance of Healthy and Sustainable Food Choices. WWF, Surrey.

Marsden, T. and Morley, A. 2014. Current Food Questions and Their Scholarly Challenges: Creating and Framing a Sustainable Food Paradigm. In: Marsden, T. and Morley, A. eds. Sustainable Food Systems: Building a New Paradigm. Oxford: Routledge, pp. 1-29 
McMichael, A.J. 2005. Integrating Nutrition with Ecology: Balancing the Health of Humans and Biosphere. Public Health Nutrition 8(6a), pp. 706-715

Montagu, I. 2016. Chapter 6: Diet (pp.142-178). The Scottish Health Survey: A National Statistic Publication for Scotland (2015 Edition, Volume 1, Main Report). The Scottish Government, Edinburgh

Morgan, K. 2008. Greening the Realm: Sustainable Food Chains and the Public Plate. Regional Studies 42(9), pp. 1237-1250

Morgan, K. 2015a. Good Food for all: The Senedd Papers \#3. Institute of Welsh Affairs, Cardiff

Morgan, K. 2015b. Nourishing the city: The rise of the urban food question in the Global North. 36 Urban Studies 52(8), pp. 1379-1394

Morgan, K. and Sonnino, R. 2010. The Urban Foodscape: World Cities and the New Food Equation. Cambridge Journal of Regions, Economy and Society 3(2), pp. 209224

Morgan, K. and Sonnino, R. 2013. The School Food Revolution: Public Food and the Challenge of Sustainable Development. London: Earthscan

Oxfam 2012. The Food Transformation: Harnessing Consumer Power To Create a Fair Food Future

Public Health England 2014. Healthier and More Sustainable Catering: Nutrition Principles. The Scientific Principles for Developing Nutrient-based Standards for Planning Nutritionally Balanced Menus. Public Health England, London

School Food Trust 2015. School Lunch and Learning Behaviour in Secondary Schools: an Intervention Study. https://www.ncbi.nlm.nih.gov/pubmed/20808337 [Accessed on 19th November 2019]

School Meals Review Panel 2005. Turning the Tables: Transforming School Food. Department of Health, UK Government, London

Smith, J., Andersson, G., Gourlay, R., Karner, S. Mikkelson, B. E., Sonnino, R. and Barling, D. 2016. Balancing Competing Policy Demands: the Case of Sustainable Public Sector Food Procurement. Journal of Cleaner Production 112, Part 1, pp. 249256

Sonnino, R. 2016. The New Geography of Food Security: Exploring the Potential of Urban Food Strategies. Geographical Journal 182(2), pp. 190-200 
Sonnino, R. and McWilliam, S. 2011. Food Waste, Catering Practices and Public Procurement: A Case Study of Hospital Food Systems in Wales. Food Policy 36(6), pp. 823-829

WHO 2014. Global Status Report on Noncommunicable Diseases 2014. World Health Organization, Geneva

WHO 2016. Global Report on Diabetes. World Health Organization, Geneva

Roberta Sonnino. Professor of Environmental Policy and Planning, Director of Impact School of Geography and Planning. sonninor@cardiff.ac.uk 